\title{
Pregnancy and contraception - the perspective of HIV-positive and negative women
}

\author{
Chinedu O Oraka*, Tochukwa S Egbunu, Samuel C Ani \\ From 17th International Symposium on HIV and Emerging Infectious Diseases (ISHEID) \\ Marseille, France. 23-25 May 2012
}

\section{Objective}

To understand pregnancy intentions and contraception knowledge and use among HIV-positive and negative women in the prevention of mother-to-child transmission (PMTCT) program.

\section{Design}

A cross-sectional survey of 236 HIV-positive and 162 HIV-negative postpartum women interviewed within 12 months of their expected delivery date in a public-sector health facility providing PMTCT services.

\section{Methods}

Bi-variant analyses explored fertility intentions, and family planning knowledge and use by HIV status. Multivariate analysis identified socio-demographic and service deliveryrelated predictors of reporting a desire for additional children and modern family planning use.

\section{Results}

HIV-positive women were less likely to report wanting additional children than HIV-negative women (8 vs. $49 \%$, $\mathrm{P}<0.001$ ), and although a majority of women reported discussing family planning with a health worker during their last pregnancy (HIV-positive 79\% vs. HIV-negative $69 \%, \mathrm{P}=0.0$ ), modern family planning use remained low in both groups (HIV-positive $43 \%$ vs. HIV-negative $12 \%$, $\mathrm{P}<0.001)$. Condoms were the most commonly used method among HIV positive women (31\%), whereas withdrawal was most frequently reported among HIV-negative women (19\%). In multivariate analysis, HIV-negative women were 16 times more likely to report wanting additional children and nearly $85 \%$ less likely to use modern family planning. Women who reported making two or less

* Correspondence: eduoraka@gmail.com

Build Africa Research Capacity, Lagos, Nigeria antenatal care visits were $77 \%$ less likely to use modern family planning.

\section{Conclusion}

Our results highlight success in provision of family planning counseling in PMTCT services. As family planning use was low among HIV-positive and negative women, further efforts are needed to improve uptake of modern methods, including dual protection, in the PMTCT settings.

Published: 25 May 2012

doi:10.1186/1742-4690-9-S1-P78

Cite this article as: Oraka et al:: Pregnancy and contraception - the perspective of HIV-positive and negative women. Retrovirology 20129 (Suppl 1):P78.
Submit your next manuscript to BioMed Central and take full advantage of:

- Convenient online submission

- Thorough peer review

- No space constraints or color figure charges

- Immediate publication on acceptance

- Inclusion in PubMed, CAS, Scopus and Google Scholar

- Research which is freely available for redistribution
C Biomed Central

\section{()

C 2012 Oraka et al; licensee BioMed Central Ltd. This is an Open Access article distributed under the terms of the Creative Commons Attribution License (http://creativecommons.org/licenses/by/2.0), which permits unrestricted use, distribution, and reproduction in any medium, provided the original work is properly cited. 